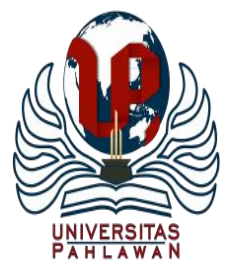

Edukatif : Jurnal Ilmu Pendidikan Volume 3 Nomor 5 Tahun 2021 Halm 1910 - 1917

EDUKATIF: JURNAL ILMU PENDIDIKAN

Research \& Learning in Education

https://edukatif.org/index.php/edukatif/index

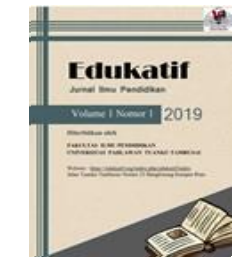

\title{
Peningkatan Keterampilan Membaca Dengan Menggunakan Media Audio Visual Di Sekolah Dasar
}

\author{
Kuncoro Adi Saputro ${ }^{1 凶}$, Christina Kartika Sari ${ }^{2}$, SW Winarsi ${ }^{3}$ \\ Pendidikan Profesi Guru, Universitas Muhammadiyah Surakarta, Indonesia ${ }^{1,2}$ \\ Sekolah Dasar Negeri 04 Kemiri, Kab Karanganyar, Indonesia ${ }^{3}$ \\ E-mail : kuncoroadi1993@gmail.com ${ }^{1}, \underline{\text { christina.k.sari@ ums.ac.id }}{ }^{2}, \underline{\text { swwinarsi@ yahoo.com }}^{3}$
}

\begin{abstract}
Abstrak
Penelitian ini di latarbelakangi oleh rendahnya keterampilan membaca di kelas II SDN 04 Kemiri Kecamatan Kebakkramat Kabupaten Karanganyar. Adapun rumusan masalah sebagai berikut, apakah penggunaan media audio visual dapat meningkatkan keterampilan membaca siswa SDN 04 Kemiri. Tujuan dari penelitian ini adalah untuk meningkatkan keterampilan membaca dengan menggunakan media audio visual. Jenis Penelitian yang digunakan adalah Penelitian Tindakan Kelas (PTK). Lokasi penelitian di kelas II SDN 04 Kemiri. Subjek penelitian sebanyak 22 siswa kelas II. Tenik pengumpulan data menggunakan teknik tes dan teknik non tes. Instrumen penelitian adalah lembar tes dan lembar non tes. Hasil penelitian keterampilan membaca menggunakan media audio visual kelas II SDN 04 Kemiri mengalami peningkatan. Siklus I hasil keterampilan membaca siswa tuntas 15 siswa $(68,19 \%)$ dan 7 siswa $(31,81 \%)$ tidak tuntas. Sedangkan untuk hasil pengamatan aktivitas siswa dengan peringkat 15 siswa (68,19\%), Baik (B), 4 siswa (18,18\%), Cukup (C) dan 3 siswa (13,63\%), Kurang (D). Pada siklus II keterampilan membaca siswa tuntas 21 siswa $(95,46 \%)$ dan 1 siswa $(4,54)$ tidak tuntas. Aktivitas siswa dengan peringkat Amat Baik (A) 7 siswa $(31,82 \%)$, Baik (B), 14 siswa $(63,64 \%)$ dan 1 siswa $(4,54 \%)$, Cukup (C).
\end{abstract}

Kata Kunci : Media audio visual, keterampilan membaca.

\begin{abstract}
This research was motivated by the low reading skills in class II SDN 04 Kemiri, Kebakkramat District, Karanganyar Regency. The formulation of the problem is as follows, whether the use of audio-visual media can improve the reading skills of SDN 04 Kemiri students. The purpose of this study was to improve reading skills by using audio-visual media. The type of research used is Classroom Action Research (CAR). The research location is in class II SDN 04 Kemiri. The research subjects were 22 class II students. Data collection techniques using test techniques and non-test techniques. The research instrument is a test sheet and a non-test sheet. The results of the research on reading skills using audio-visual media for class II SDN 04 Kemiri have increased. In the first cycle, the results of the students' reading skills were completed by 15 students $(68.19 \%)$ and 7 students (31.81\%) did not complete. As for the results of observing student activities with a rating of 15 students (68.19\%), Good (B), 4 students (18.18\%), Enough (C) and 3 students (13.63\%), Less (D). In the second cycle, 21 students (95.46\%) completed reading skills and 1 student (4.54) did not complete. Student activities with a rating of Very Good (A) 7 students (31.82\%), Good (B), 14 students (63.64\%) and 1 student (4.54\%), Enough (C).
\end{abstract}

Keywords: Audio visual media, reading skills.

Copyright (c) 2021 Kuncoro Adi Saputro, Christina Kartika Sari, SW Winarsi

$\triangle$ Corresponding author

Email : kuncoroadi1993@gmail.com

DOI : https://doi.org/10.31004/edukatif.v3i5.690

ISSN 2656-8063 (Media Cetak)

ISSN 2656-8071 (Media Online) 
1911 Peningkatan Keterampilan Membaca Dengan Menggunakan Media Audio Visual Di Sekolah DasarKuncoro Adi Saputro, Cristina Kartika Sari, SW Winarsi

DOI : https://doi.org/10.31004/edukatif.v3i5.690

\section{PENDAHULUAN}

Bahasa merupakan media komunikasi dalam proses interaksi manusia. Bahasa memiliki peran sentral dalam perkembangan intelektual, sosial dan emosional siswa dan merupakan penunjang keberhasilan dalam mempelajari semua mata pelajaran. Menurut Kridalaksana dan Djoko Kentjono dalam (Chaer, 2014) bahasa adalah sistem lambang bunyi yang arbitrer yang digunakan oleh para anggota kelompok sosial untuk bekerja sama, berkomunikasi, dan mengidentifikasikan diri. Proses kegiatan belajar mengajar pada pembelajaran Bahasa Indonesia tidak lepas dari fungsi dan peran seorang guru dalam menentukan output pendidikan. Peran guru dalam kegiatan pembelajaran adalah menyusun desain pembelajaran sedemikian rupa sehingga bisa terjadi pembelajaran yang menarik. Pembelajaran bahasa Indonesia di Sekolah Dasar (SD) dapat memberikan kemampuan dasar berbahasa yag diperlukan untuk melanjutkan pendidikan di sekolah menengah maupun untuk menyerap ilmu yang dipelajari lewat bahasa itu. Selain itu pembelajaran bahasa Indonesia juga dapat membentuk sikap berbahasa yang positif serta memberikan dasar untuk menikmati dan menghargai sastra Indonesia. Dalam pembelajaran bahasa Indonesia perlu diperhatikan pelestarian dan pengembangan nilai-nilai luhur bangsa, serta pembinaan rasa persatuan nasional.

Pembelajaran Bahasa Indonesia merupkan salah satu materi penting yang diajarkan di sekolah dasar, karena mempuyai kedudukan dan fungsi yang sangat penting bagi kehidupan sehari-hari. Dari segi infrastruktur untuk membaca, Indonesia sudah setara dengan negara lain. Sekolah-sekolah telah tersedia perpustakaan yang menyediakan banyak buku bacaan dari non fiksi hingga fiksi. Kenyataan di lapangan, buku yang ada di perpustakaan hanya sebagai koleksi bukan untuk dibaca. Terutama di sekolah dasar banyak anakanak yang masih mengalami kesulitan dalam membaca disebabkan karena kurang minatnya untuk mengeja kata dan membaca buku. Menumbuhkan minat baca di sekolah dasar bukan hal yang mudah, tetapi tetap harus diupayakan. Hal ini membutuhkan kerjasama antara guru dengan siswa.

Guru sebagai fasilitator harus mampu mengemas kegiatan pembelajaran yang di dalamnya mampu meningkatkan minat baca siswa. Proses pembelajaran harus diarahkan agar siswa memperoleh informasi sendiri dengan membaca buku. Dengan demikian siswa aktif dan berusaha sendiri untuk mencari informasi lebih banyak. Menurut (Tarigan, 2008) membaca adalah suatu proses yang dilakukan serta dipergunakan oleh pembaca untuk memperoleh pesan yang hendak disampaikan oleh penulis. melalui media kata-kata/bahasa tulis. Dalam hal ini, membaca adalah suatu usaha untuk menelusuri makna yang ada dalam tulisan. Membaca merupakan aktivitas atau proses penangkapan dan pemahaman sejumlah pesan (informasi) dalam bentuk tulisan. Sedangkan menurut (Somadyo, 2011) membaca merupakan kegiatan interaktif untuk memetik dan memahami makna yang terkandung dalam bahan tertulis. Membaca adalah kegiatan otak untuk mencerna dan memahami serta memaknai simbol-simbol sehingga merangsang otak untuk melakukan olah pikir memahami makna yang terkandung dalam rangkaian simbol-simbol tersebut. Dengan demikian membaca merupakan kegiatan yang penting bagi seseorang dalam hal ini siswa sekolah dasar yang ingin meningkatkan diri untuk memperluas wawasannya.

Berdasarkan hasil observasi melalui wawancara kepada wali kelas II di SDN 04 Kemiri bahwa keterampilan membaca siswa di SD Negeri tersebut sangat rendah. Hal itu terjadi karena Guru tidak menggunakan media yang mampu menarik minat siswa, selain itu siswa juga belum memiliki kemampuan membaca dengan lancar dan benar sehingga sulit mengikuti pembelajaran membaca, Hal ini mengakibatkan keterampilan membaca siswa rendah. Dilihat dari hasil ulangan harian siswa tema 5 materi membaca teks percakapan di kelas II SDN 04 Kemiri, dari 22 siswa terdapat 11 siswa tuntas 50\% dan 11 siswa tidak tuntas $50 \%$. Oleh karena itu, guru harus mengupayakan suatu cara untuk meningkatkan keterampilan membaca bagi siswa yang belum tuntas dalam ulangan harian membaca, lewat sarana atau prasarana yang ada di ruang lingkup sekolah. Di sekolah dasar saat ini sudah terdapat sarana yang sangat menunjang sebagai alat bantu untuk meningkatkan keterampilan membaca. Sarana penunjang pembelajaran tersebut adalah Liquid Cryistal 
1912 Peningkatan Keterampilan Membaca Dengan Menggunakan Media Audio Visual Di Sekolah DasarKuncoro Adi Saputro, Cristina Kartika Sari, SW Winarsi

DOI : https://doi.org/10.31004/edukatif.v3i5.690

Display (LCD), laptop dan alat penunjang lainnya. Namun disisi lain, pemanfaatan fasilitas di sekolah belum dilaksanakan secara maksimal dalam rangka meningkatkan keterampilan membaca siswa. Fasilitas yang ada di sekolah dapat digunakan oleh guru salah satunya melalui Media Audio Visual.

Kata media merupakan bentuk jamak dari kata medium. Medium dapat didefinisikan sebagai perantara atau pengantar terjadinya komunikasi dari pengirim menuju penerima. Batasan mengenai pengertian media dalam pendidikan yakni media yang digunakan sebagai alat dan bahan kegiatan pembelajaran (Daryanto, 2016). Pengertian media menurut (Arsyad, 2014), media pendidikan adalah komponen sumber belajar atau wahana fisik yang mengandung materi intruksional di lingkungan siswa yang dapat merangsang siswa untuk belajar. Media pembelajaran dapat dipahami sebagai, segala sesuatu yang dapat menyampaikan dan menyalurkan pesan dari sumber secara terencana sehingga tercipta lingkungan belajar yang kondusif dimana penerimanya dapat melakukan proses belajar secara efisien dan efektif (Munadi, 2013). Jadi dapat disimpulkan bahwa media adalah suatu alat bantu yang dapat dipergunakan untuk menyalurkan pesan dan dapat merangsang pikiran, dapat membangkitkan semangat, perhatian, aktifitas dan partisipasi siswa sehingga dapat menunjang terjadinya proses belajar mengajar yang diharapkan antara guru dan peserta didik.

Penggunaan media audio visual bukan sekedar upaya untuk membantu guru dalam meningkatkan keterampilan membaca siswa, tetapi lebih dari itu. sebagai usaha memudahkan siswa dalam meningkatkan kreatifitas membaca siswa. Media Audio Visual memang pantas digunakan guru, bukan hanya alat bantu guru namun diharapkan akan timbul kesadaran baru bahwa media pembelajaran menjadi salah satu bagian penting dalam sistem pendidikan, sehingga dapat dimanfaatkan semaksimal mungkin untuk membantu kelancaran dibidang tugas yang diemban untuk kemajuan dan meningkatkan kualitas siswa. Media Audio Visual memiliki kelebihan berupa bahan ajar yang dapat diterima sehingga akan lebih mudah dipahami oleh siswa. Proses belajar mengajar akan lebih variatif mengiringi komunikasi verbal melalui penuturan oleh guru. Media audio visual dapat meminimalisir kecenderungan rasa bosan dan jenuh siswa akibat pembelajaran yang monoton, dengan media audio visual, dapat mengubah suasana pembelajaran membaca menjadi lebih menyenangkan dan lebih meningkatkan keterampilan membaca (Sayidiman, 2012). Berdasarkan latar belakang masalah di atas, peneliti tertarik untuk melaksanakan penelitian tindakan kelas dengan judul "Peningkatan Keterampilan Membaca dengan Bantuan Media Audio Visual Pada Siswa Kelas II SDN 04 Kemiri”.

Media audio visual adalah merupakan media perantara atau penggunaan materi dan penyerapannya melalui pandangan dan pendengaran sehingga membangun kondisi yang dapat membuat siswa mampu memperoleh pengetahuan, keterampilan, atau sikap. Media audiovisual merupakan media pembelajaran yang pemakaiannya dilakukan dengan cara diproyeksikan melalui arus listrik dalam bentuk suara, misalnya, radio, tape recorder dan media yang diproyeksikan ke layar monitor dalam bentuk gambar dan suara misalnya, televisi, video, film, $D V D$ dan $V C D$. Media ini mampu menggugah perasaan dan pikiran siswa, memudahkan pemakaian materi dan menarik minat siswa untuk belajar. Terdapat alat yang membantu fungsi dalam menampilkan gambar, alat tersebut berupa LCD projector yang akan menampilkan gambar melalui layar. Alat yang membantu fungsi untuk mendengarkan suara agar terdengar jelas adalah pengeras suara (Speaker Active). Berdasarkan uraian tersebut di atas, dapat disimpulkan bahwa media audiovisual merupakan media pembelajaran yang pemakaiannya dilakukan dengan cara diproyeksikan ke layar monitor melalui arus listrik dalam bentuk gambar dan suara, misalnya televisi, video, film, DVD, dan VCD. Dalam penelitian ini media audiovisual yang dimaksud adalah media video rekaman pembacaan berita oleh pembaca berita televisi.

Keterampilan adalah suatu kemampuan dalam melakukan sesuatu. Seseorang dikatakan mampu apabila ia bisa melakukan sesuatu yang harus ia lakukan. Pengertian keterampilan dalam konteks pembelajaran adalah usaha untuk memperoleh kompetensi cekat, cepat dan tepat dalam menghadapi permasalahan belajar (Muttaqin, 2008). Sedangkan Marabimin dalam (Suwarjo, 2008) menyatakan bahwa keterampilan membaca adalah keterampilan reseptif. Disebut reseptif karena dengan membaca seseorang akan memperoleh informasi, 


\section{Peningkatan Keterampilan Membaca Dengan Menggunakan Media Audio Visual Di Sekolah Dasar- Kuncoro Adi Saputro, Cristina Kartika Sari, SW Winarsi

memperoleh ilmu dan pengetahuan serta pengalaman-pengalaman baru. Berdasarkan beberapa pendapat tersebut dapat disimpulkan bahwa keterampilan membaca adalah kemampuan yang diperoleh siswa selama mengikuti proses pembelajaran. Dengan siswa terampil membaca maka akan melakukan proses produksi yang dapat menghasilkan pengetahuan, pengalaman, dan sikap-sikap baru. Seperti halnya sebuah perusahaan yang menghasilkan sesuatu melalui proses mengolah seseorang dalam kegiatan membaca bertujuan untuk mengolah bacaan demi memperoleh informasi.

Beberapa penelitian menunjukkan peningkatan keterampilan membaca menggunakan media audio visual. Diantaranya oleh (Muhlisin, Usada and Djaelani, 2015) nilai rata-rata prasiklus 69,10. Siklus I nilai rata-rata pretes 69,61 . Setelah penggunaan media audio visual nilai postest 74,52. Siklus II nilai rata-rata pretest 75,57 . Setelah penggunaan media audio visual nilai postest 80,04 . Sejalan pada penelitian tersebut (Ratni dan Raden Apriadi, 2019), dilihat dari hasil dibuktikan dengan nilai rata-rata pra tindakan 30,77\% meningkat pada siklus I $61,54 \%$ dan pada siklus II mengalami peningkatan sebesar $84,62 \%$. Demikian pembelajaran menggunakan media audio visual dapat meningkatkan keterampilan membaca siswa kelas II SDN 04 Kemiri Tahun Pelajaran 2020/2021.

Berdasarkan permasalahan observasi pada SD Negeri 4 Kemiri, dapat diasumsikan bahwa pembelajaran yang dilakukan belum maksimal. Perlu adanya perbaikan pembelajaran yang tepat untuk meningkatkan keterampilan membaca siswa. Solusi untuk meningkatkan masalah tersebut yaitu dengan menggunakan media audio visual. Media audio visual adalah media kombinasi antara audio dan visual yang dikombinasikan dengan kaset audio yang mempunyai unsur suara dan gambar yang biasa dilihat, misalnya rekaman video, slide suara dan sebagainya.

\section{METODE PENELITIAN}

Peneliti dalam melaksanakan penelitian termasuk jenis penelitian tindakan kelas. Jenis penelitian ini adalah penelitian tindakan kelas. (Mulyasa, 2013) penelitian tindakan kelas merupakan upaya untuk mencermati kegiatan belajar kelompok peserta didik dengan memberikan tindakan yang dimunculkan guru bersama-sama antara guru dengan peserta didik dibawah bimbingan guru yang bertujuan memperbaiki dan meningkatkan kualitas pembelajaran. Menurut (Rubiyanto, 2011) penelitian tindakan kelas adalah suatu pencermatan terhadap kegiatan pembelajaran, berupa tindakan yang sengaja dimunculkan dan terjadi dalam sebuah kelas. Kemudian pendapat berbeda mengungkapkan, PTK merupakan kegiatan untuk mengamati kejadian dalam pembelajaran di kelas guna memperbaiki hasil belajar menjadi lebih baik dalam proses pembelajaran ungkap Bahri pada (Hartono, 2009).

Pelaksanaan penelitian di SD Negeri 4 Kemiri semester 2 tahun ajaran 2020 / 2021. SD Negeri 4 Kemiri merupakan SD yang terletak di dusun Dawung, Kecamatan Kebakkramat, Kabupaten Karanganyar. Kemudian subjek penelitian ini merupakan siswa kelas II SD Negeri 4 Kemiri berjumlah 22 siswa. Pelaksanaan penelitian ini bekerjasama dengan guru kelas II SD Negeri 4 Kemiri yaitu Ibu Sugiyanti, S.Pd.SD dalam melaksanakan penelitian ini.

Prosedur yang akan dilakukan mencakup empat langkah pokok, yaitu: (1) merumuskan masalah dan merencanakan tindakan (planning), (2) melaksanakan tindakan (acting), (3) merefleksikan (reflecting) hasil pengamatan, dan (4) perbaikan atau perubahan perencanaan (replaning) untuk mengembangkan tingkat keberhasilan. Dalam penelitian ini peneliti menggunakan dua teknik, yaitu teknik tes dan non tes. Teknik tes dilakukan dengan bantuan lembar evaluasi pada tiap akhir pembelajaran, serta tes formatif pada tiap akhir siklus. Pelaksanaan tes bertujuan untuk mengetahui hasil belajar aspek kognitif siswa. Sedangkan teknik nontes dilakukan melalui pengamatan. Pengamatan dilakukan untuk mengetahui aktivitas siswa dan keterampilan guru selama proses pembelajaran. Inistrumen yang digunakan dalam tes ini adalah lembar tes dan lembar observasi aktivitas siswa dan keterampilan guru. 
1914 Peningkatan Keterampilan Membaca Dengan Menggunakan Media Audio Visual Di Sekolah DasarKuncoro Adi Saputro, Cristina Kartika Sari, SW Winarsi

Teknik analisis data yang digunakan dalam penelitian ini yaitu teknik analisis data kuantitatif dan teknik analisis data kualitatif. Data kuantitatif diperoleh dari hasil belajar siswa yaitu dari ranah kognitif. Hasil tes siswa dikoreksi, diberi nilai, dan dianalisis dengan membandingkan nilai KKM dari SDN 04 Kemiri. Siswa yang tuntas belajar adalah siswa yang nilainya $\geq 73$. Data kualitatif diperoleh dari data hasil observasi terhadap keterampilan guru dan aktivitas siswa dalam mengikuti pembelajaran.

Untuk mengetahui keberhasilan dari penelitian ini, dapat dilihat melalui indikator sebagai berikut: 1) Keterampilan siswa kelas II SD Negeri 04 Kemiri pada pembelajaran telah mencapai KKM yang telah ditentukan yaitu $\geq 73$ dengan KKM klasikal $\geq 75 \%$, 2) Aktivitas siswa khususnya keaktifan dalam pembelajaran Bahasa Indonesia menggunakan media audio visual dikatakan meningkat adalah minimal kategori baik yaitu $>75$ dengan klasikal $\geq 70 \%$.

\section{HASIL DAN PEMBAHASAN}

Analisis dilakukan untuk mengetahui hasil penelitian telah mencapai kriteria ketuntasan atau belum, yang terdiri dari ketuntasan individu maupun klasikal. Analisis juga dilakukan pada aktivitas siswa dan keterampilan guru yang berpengaruh terhadap kriteria ketuntasan keterampilan membaca. Analisis dalam penelitian ini dilakukan berdasarkan kriteria keberhasilan pembelajaran yang telah ditentukan sesuai dengan standar yang ditetapkan di SD Negeri 04 Kemiri Kecamatan Kebakkramat Kabupaten Karanganyar yaitu KKM keterampilan membaca sebesar $73 \mathrm{KKM}$ klasikal sebesar $\geq 75 \%$.

Keterampilan membaca siswa dalam pembelajaran Bahasa Indonesia didapatkan dari bacaan berbentuk teks bacaan bacaan yang diberikan setiap siklus. Keterampilan membaca yang diperoleh kemudian diolah untuk memperoleh informasi ketuntasan keterampilan individu dalam keterampilan membaca di kelas II SD Negeri 04 Kemiri yaitu sebesar $\geq 73$. Berdasarkan kriteria ketuntasan individu tersebut, kemudian diolah untuk memperoleh ketuntasan keterampilan klasikal. Ketuntasan keterampilan dalam pembelajaran Bahasa Indonesia si sekolah ini yaitu sebesar $\geq 75 \%$. Perolehan keterampilan membaca Bahasa Indonesia pada siswa kelas II SD Negeri 04 Kemiri mengalami peningkatan di setiap siklusnya. Penelitian ini dilaksanakan sampai pada siklus II. Perolehan ketuntasan keterampilan membaca siswa pada tindakan siklus I, dan siklus II disajikan dalam tabel berikut.

Tabel 1 Ketuntasan Keterampilan Membaca

\begin{tabular}{cccc}
\hline \multicolumn{2}{c}{ Ketuntasan Klasikal } & \multirow{2}{*}{ Peningkatan } & Kriteria \\
\cline { 1 - 2 } Siklus I & Siklus II & & \\
\hline 15 Siswa & 21 Siswa & & Tuntas \\
$(68,19 \%)$ & $(95,46 \%)$ & 6 Siswa $(27,27 \%)$ & \\
\cline { 1 - 2 }$(3$ Siswa & 1 Siswa & & Tidak Tuntas \\
$(31,81 \%)$ & $(4,54 \%)$ & & \\
\hline
\end{tabular}

Berdasarkan perolehan nilai keterampilan membaca pada siklus I dan siklus II telah mencapai kriteria ketuntasan klasikal membuktikan bahwa penggunaan media audio visual dalam pembelajaran Bahasa Indonesia di kelas II SD Negeri 04 Kemiri Kecamatan Kebakkramat Kabupaten Karanganyar dapat meningkatkan keterampilan membaca, karena telah mencapai indikator keberhasilan ketuntasan klasikal yang ditetapkan yaitu $\geq 75 \%$ terbukti pada siklus II terjadi peningkatan yaitu ketuntasan klasikalnya mencapai $95,46 \%$. 
1915 Peningkatan Keterampilan Membaca Dengan Menggunakan Media Audio Visual Di Sekolah DasarKuncoro Adi Saputro, Cristina Kartika Sari, SW Winarsi

DOI : https://doi.org/10.31004/edukatif.v3i5.690

Penilaian aktivitas siswa dilakukan dengan menggunakan lembar observasi dengan 6 indikator penilaian. Penilaian ini dilakukan pada saat pembelajaran sedang berlangsung di setiap siklus yaitu sebanyak 2 siklus. Perolehan nilai aktivitas siswa selama pembelajaran di setiap siklus disajikan dalam tabel berikut:

Tabel 2 Data Nilai Aktivitas Siswa

\begin{tabular}{cccc}
\hline Siklus I & Siklus II & Kriteria & Peningkatan \\
\hline 15 Siswa $(68,19 \%)$ & 21 Siswa $(95,46 \%)$ & Tuntas & 6 Siswa $(27,27 \%)$ \\
\hline 7 Siswa $(31,81 \%)$ & 1 Siswa $(4,54 \%)$ & Tidak Tuntas & 6 Siswa $(27,27 \%)$
\end{tabular}

Berdasarkan hasil observasi aktivitas siswa keterampilan membaca pada pembelajaran Bahasa Indonesia menggunakan media audio visual pada pembelajaran siklus II data menunjukkan bahwa 7 siswa $(31,82 \%)$ berada pada peringkat Amat Baik (A), 14 siswa $(63,64 \%)$ berada pada peringkat Baik (B) dan 1 siswa $(4,54 \%)$, Cukup (C). Sehingga dapat dinyatakan yaitu sebesar $>75$ dapat dinyatakan bahwa aktivitas siswa pada siklus II dinyatakan sudah cukup dan sudah memenuhi kriteria keberhasilan penelitian.

Hasil penelitian diperoleh dari keterampilan membaca, aktivitas siswa dan keterampilan guru. Penelitian tindakan kelas ini dilaksanakan dalam dua siklus. Siklus I sampai siklus II terjadi peningkatan perolehan keterampilan membaca pembelajaran Bahasa Indonesia pada siswa kelas II SD Negeri 04 Kemiri terjadi peningkatan oleh karena adanya penggunaan media audio visual dapat meningkatkan aktivitas dan keterampilan siswa secara konkrit terhadap materi dalam proses pembelajaran sehingga keterampilan membaca siswa meningkat. Peningkatan keterampilan membaca tersebut dapat dilihat dari nilai siklus I dengan tes evaluasi didapatkan data hasil yaitu $68,19 \%$. Pada siklus II dengan tes evaluasi didapatkan data hasil yaitu 95,46\%, membuktikan adanya peningkatan keterampilan membaca siswa. Pada pembelajaran dengan menggunakan media audio visual aktivitas siswa cenderung mengalami peningkatan. Peningkatan ini disebabkan timbulnya interaksi antarsiswa yang lebih terarah, kerja sama antar siswa menjadi lebih akrab. Hal ini sesuai dengan teori yang dikemukakan oleh (Huda, 2013) "Melatih siswa untuk berinteraksi secara baik dengan teman sekelasnya". Keterampilan guru dalam menerapkan media audio visual keterampilan membaca pada pembelajaran Bahasa Indonesia meningkat.

Dengan menerapkan media audio visual guru berperan sebagai fasilitator. Guru menerangkan materi, guru menjelaskan terlebih dahulu materinya kemudian menjelaskan langkah-langkah kegiatan yang akan dilakukan siswa pada pembelajaran yang menggunakan media audio visual. Hal ini didukung oleh (Huda, 2013) "Penyajian materi yang terarah dan sistematis, sebab guru terlebih dahulu menjabarkan uraian materi sebelum pelaksanaan pembelajaran".

Adanya peningkatan keterampilan membaca pada siswa ini karena siswa merasa terbantu dan senang dengan penggunaan media audio visual yang diberikan oleh guru. Penggunaan media audio visual dalam penyampaian materi besar pengaruhnya terhadap hasil belajar siswa. Siswa terlihat bersemangat dalam pembelajaran di kelas dan sesuatu hal yang baru untuk mereka dan siswa dapat menjawab pertanyaan guru dengan baik. Belajar menggunakan media audio visual membuat siswa bisa lebih memahami materi secara jelas. Motivasi siswa pun terus meningkat karena siswa belajar dengan menggunakan media audio visual. Hal ini seperti yang kemukakan oleh Menurut (Azhar Arsyad, 2011) media pembelajaran adalah segala sesuatu yang dapat digunakan untuk menyampaikan pesan atau informasi dalam proses belajar mengajar sehingga merangsang minat belajar dan motivasi siswa. (Rusman, 2016) mengungkapkan bahwa penggunaan media pembelajaran yang sesuai dengan karakteristik kebutuhan siswa dan materi yang hendak disampaikan, akan turut membangkitkan rasa ingin tahu, motivasi, konsentrasi dan hasil belajar serta sebagai stimulus dalam 
1916 Peningkatan Keterampilan Membaca Dengan Menggunakan Media Audio Visual Di Sekolah DasarKuncoro Adi Saputro, Cristina Kartika Sari, SW Winarsi

DOI : https://doi.org/10.31004/edukatif.v3i5.690

kegiatan pembelajaran. Adapun perbaikan yang akan diterapkan pada siklus II adalah dengan menciptakan suasana pembelajaran yang santai dan menyenangkan.

Sebagian siswa telah mampu meningkatkan keterampilan membaca dengan ketuntasan belajar sesuai dengan kriteria. Ada perbedaan antara tes sebelum dilakukan penggunaan media audio visual dan sesudah proses belajar mengajar dengan menggunakan media audio visual. Melalui media audio visual siswa dapat belajar dengan senang dan mudah mengerti dan memahami. Jika suasana belajar dicipatakan semenarik mungkin dengan media yang lebih menarik lagi, maka motivasi belajar siswa akan muncul dan terus bertambah. Dengan demikian kegiatan belajar akan berjalan dengan baik.

Berdasarkan hal tersebut pembelajaran dengan menggunakan media audio visual dapat meningkatkan keterampilan membaca siswa kelas II di SD Negeri 04 Kemiri. Hal ini dapat dilihat dari rata-rata nilai tes siswa setelah diterapkan dengan menggunakan media audio visual mengalami peningkatan di setiap siklusnya, demikian juga dengan banyaknya siswa yang telah memenuhi KKM dan mengalami peningkatan pada setiap siklusnya.

\section{KESIMPULAN}

Berdasarkan hasil penelitian tindakan kelas ini dapat disimpulkan bahwa penggunaan media audio visual dapat meningkatkan keterampilan membaca kelas II SD Negeri 04 Kemiri Kecamatan Kebakkramat Kabupaten Karanganyar. Keterampilan membaca meningkat dan aktivitas siswa meningkat. Penggunaan media audio visual dapat menarik dan mengarahkan perhatian siswa agar berkonsentrasi pada materi pelajaran yang berkaita. Selain itu siswa juga menikmati pembelajaran dan mudah memahami dan mengingat informasi yang termuat. Jadi keterampilan membaca pada pembelajaran Bahasa Indonesia pada siklus I sampai siklus II meningkat. Hal ini menunjuk kan bahwa hasil penelitian sudah mencapai keberhasilan yang sudah ditentukan. Peningkatan keterampilan membaca tersebut ditandai dengan meningkatnya dari siklus 1 ke siklus 2 . Siklus I hasil keterampilan membaca siswa tuntas 15 siswa $(68,19 \%)$ dan 7 siswa $(31,81 \%)$ tidak tuntas. Pada siklus II keterampilan membaca siswa tuntas 21 siswa $(95,46 \%)$ dan 1 siswa $(4,54)$ tidak tuntas. Dengan demikian dapat disimpulkan bahwa penggunaan media audio visual dapat meningkatkan keterampilan membaca pada siswa kelas II di SD Negeri 4 Kemiri Tahun Pelajaran 2020/2021.

\section{UCAPAN TERIMAKASIH}

Penulis dalam menyusun penelitian ini mengucapkan puji syukur kepada Allah SWT atas limpahan rahmat dan hidayah dalam Menyusun penelitian ini. Peneliti mengucapkan kepada orang tua, beserta keluarga yang telah memberikan dukungan secara moral dan materil. Terimakasih kepada Bapak/Ibu Dosen Pendidikan Profesi Guru Universitas Muhammadiyah Surakarta dan teman-teman PPL serta guru dan staf SD Negeri 04 Kemiri yang telah memberikan bimbingan dan arahannya. Semoga penelitian yang disusun dapat bermanfaat bagi semua. Serta pihak yang telah memberikan dukungan dalam peneliti.

\section{DAFTAR PUSTAKA}

Arsyad, A. (2014) Media Pembelajaran. Jakarta: PT. Rajagrafindo Persada.

Azhar Arsyad (2011) Media Pembelajaran. Jakarta : PT Raja Grafindo Persada.

Chaer, A. dan M. (2014) Bahasa Indonesia. In: Makna dan Semantik. Universitas Terbuka, Jakarta, pp. 1-39.

Daryanto (2016) Media Pembelajaran. Yogyakarta: Gava Media.

Hartono (2009) 'Langkah-langkah Penelitian Tindakan Kelas', pp. 1-24. 
1917 Peningkatan Keterampilan Membaca Dengan Menggunakan Media Audio Visual Di Sekolah DasarKuncoro Adi Saputro, Cristina Kartika Sari, SW Winarsi

DOI : https://doi.org/10.31004/edukatif.v3i5.690

Huda, M. (2013) Model-model Pengajaran dan Pembelajaran. Malang: Pustaka Pelajar.

Muhlisin, Usada and Djaelani (2015) 'Peningkatan Keterampilan Membaca Permulaan Melalui Penggunaan Metode Global Berbasis Media Audio Visual', Jurnal Didaktika Dwija Indria (SOLO).

Mulyasa (2013) Pengembangan dan Implementasi Kurikulum 2013. Bandung: Rosda.

Munadi, Y. (2013) Media Pembelajaran (Sebuah Pendekatan Baru). Jakarta: Referensi.

Muttaqin, A. (2008) Buku Ajar Asuhan Keperawatan Klien Dengan Gangguan Sistem Imunologi. Jakarta: Salemba Medika.

Ratni dan Raden Apriadi (2019) 'Meningkatkan Kemampuan Membaca dengan Menggunakan Media Visual Pada Siswa Sekolah Dasar', STKIP Hamzar Lombok Utara, 8(5), p. 55.

Rubiyanto, R. (2011) Metode Penelitian Pendidikan. Surakarta:FKIP PGSD UMS.

Rusman (2016) Model-model pembelajaran: mengembangkan profesionalisme Guru. Jakarta: Rajawali Pers.

Sayidiman (2012) Penggunaan Media Audiovisual Dalam Merangsang Minat Mahasiswa Terhadap Mata Kuliah Seni Tari. Jurnal Publikasi Pendidikan. Volume II. No. 1.

Somadyo, S. (2011) Strategi dan Teknik Pembelajaran Membaca. Yogyakarta: Graha Ilmu.

Suwarjo (2008) Pembelajaran Kooperatif dalam Apresiasi Prosa Fiksi. Malang: Surya Pena Gemilang.

Tarigan, H. G. (2008) Membaca Sebagai Suatu Keterampilan Berbahasa. Bandung: Angkasa. 